\title{
Can videogames improve balance in women over 60 years? ¿Pueden los videojuegos mejorar el equilibrio en mujeres mayores de 60 años?
} *Juan Antonio Párraga Montilla, *Pedro Ángel Latorre Román, *José Carlos Cabrera Linares, **Carlos Salazar Martínez, ***Manuel Villar Ortega, *Rafael Moreno Del Castillo, ****Victor Serrano Huete, *Emilio Lozano Aguilera

*Universidad de Jaén; **I.E.S. Santísima Trinidad (Baeza); ***I.E.S. Miguel Sánchez López (Torredelcampo); *****Universidad Isabel I. Burgos

\begin{abstract}
Objective: The aim of this study was to measure the usefulness of incorporating videogames as a physical activity training program for women above 60 years old. Methods: An intergroup, intragroup and multigroup design on three groups were used as well as experimental methodology. Women above 60 years old ( $N=43$, age $=67.74 \pm 5.03$ years), completed a proprioceptive and resistance training during three months and three sessions a week. Participants were divided into: control group $(C G)(n=11 ;$ age $=67.09 \pm 6.25$ years), does not do the experimental training. Experimental group 1 (EG1: $N=16$; age $=66.94 \pm 4.14$ years) performed a proprioceptive and resistance training program of 40 minutes, adding the use of a videogame during 20 minutes. Experimental group $2(E G 2)(N=16$; age $=69.00 \pm 4.99$ years), performed the same training without the videogame training. Results: We found an improvement in EG1 in body fat, balance with and without vision, dominant hand isometric force and $\mathrm{VO}_{2}$ max. The EG2 group improves in body mass index (BMI), body fat, non-dominant hand isometric force and $\mathrm{VO}_{2}$ max. CG does not change. Conclusion: Joining a physical training program, including proprioceptive and aerobic resistance exercises result in a weight and $\mathrm{BMI}$ drop, and $\mathrm{aVO}_{2}$ max improvement in both groups (EG1 and EG2). Additionally, if the training program is completed with the use of videogames (EG1), monopodal static balance improve more than EG1 and EG2, with and without vision, which is considered beneficial to prevent falls in women over 60 years.
\end{abstract}

Keywords: Women, Quality of living, Training program, Balance, Videogames.

Resumen. Objetivo: El objetivo de este estudio fue evaluar la utilidad de incorporar videojuegos en un programa de actividad física en mujeres mayores de 60 años. Método: Se diseñó un estudio intergrupal, intragrupo y multigrupo, así como una metodología experimental. Se implementó un entrenamiento de resistencia y propiocepción en mujeres mayores de 60 años $(\mathrm{N}=43$, Edad $=67.74 \pm 5.03$ años, durante tres meses y tres sesiones semanales. Se dividió en un grupo control $(\mathrm{GC})(\mathrm{n}=11$; Edad=67.09 \pm 6.25 años), no realizó entrenamiento. Grupo experimental 1 (GE1) (GE1: N= 16; edad= $66.94 \pm 4.14$ años), realizó un entrenamiento de resistencia y propiocepción y se añadió el uso de videojuegos durante 20 minutos. Grupo Experimental 2 (GE2) ( $\mathrm{N}=16$; edad=69.00 \pm 4.99 años), que realizó el mismo entrenamiento sin el uso de videojuegos. Resultados: Encontramos una mejora en el GE1 en grasa corporal, equilibrio con y sin visión, fuerza isométrica en la mano dominante $\mathrm{yVO}_{2} \max$. El GE2 mejoró en el índice de masa corporal (IMC), grasa corporal, fuerza isométrica en la mano no dominante $\mathrm{yVO}_{2}$ max. No se encontraron cambios en el GC. Conclusión: La inclusión en un programa físico de entrenamiento que incluye propiocepción y ejercicios aeróbicos de resistencia reduce el peso, el IMC y el $\mathrm{VO}_{2}$ max en ambos grupos (GE1, GE2). Además, si el programa de entrenamiento es completado con el uso de videojuegos (GE1), se mejora el equilibrio estático monopodal, con y sin visión, lo cual es considerado beneficioso para prevenir caídas en mujeres mayores de 60 años. Palabras clave: Mujeres, Calidad de vida, programa de entrenamiento, Equilibrio, Videojuegos.

\section{Introduction}

An unprecedented rise of people above 60 years old can be seen in current society, predominated by the female gender (Horne, Skelton, Speed, \& Tood, 2014). On a global level, this segment of the population is growing faster (Flack, Davy, Hulver, Winett, Frisard,

Fecha recepción: 08-11-20. Fecha de aceptación: 18-03-21

Juan Antonio Párraga Montilla

jparraga@ujaen.es
\& Davy, 2011), estimating that $29 \%$ of the global population will be above 60 years in 2025 (Rahman, 2007). The quality of life of this group may be impaired due to multiple factors such as sarcopenia. Sarcopenia is one of the factors that can increase functional difficulties in older people (Ruthig, Chipperfield, Newall, Perry, \& Hall, 2007). Cases exist of people with total mobility becoming extremely immobile such as people who suffer from encephalic vascular accidents, disabling injuries, or immunological diseases. Other people show a progressive deterioration due to chronic illness as it is 
the case of osteoarthritis, neoplastic diseases, cardiac and respiratory failure or cognitive diseases like Alzheimer's (McNaull,Todd, McGuinness, \& Passmore, 2010).

Walking ability can decrease due to falls and frequent hospitalizations (Scheffer, Schuurmans, Van Dijk, Vand der Hooft, \& De Rooij, 2007). Also, falling is a public health problem (Blank et al., 2011), as constitutes the main cause of the accident from 60 years of age and it might even have fatal consequences for elder over 80 years (Meisler, et al., 2011). Every fall can produce muscle-skeletal injuries and a loss of confidence in older people to perform daily activities. Nowadays, there is no agreement about the causes of falls, but some authors concluded that it is a consequence of several aspects, as intrinsic to the own person as related to the environment (Caicedo, Reginfo, \& Rodríguez, 2016; Hill, Nguyen, Shaha, Wenzel, Deforge, \& Spellbring, 2009). The knowledge of these aspects allows us to design intervention and prevention strategies to decrease their consequences. In that sense, it is necessary to promote research about health and ageing related diseases to improve the quality of life in older people (Jin, Simpkins, Ji, Leis, \& Stambler, 2015). During the ageing process occurs an involution in their physical condition, sharply manifested by a decline in physical basic capabilities as strength, cardio-respiratory capacity, flexibility, coordination, balance and body composition (Hernandez, Goldberg, \& Alexander, 2010; Shields, Tremblay, Laviolette, Craig, Janssen, \& Gorber, 2010).

There is a $27 \%$ of people over 65 years who have a high probability of falling off at least once a year, with a high likelihood of falling again after the first fall (Ganz, Bao, Shekelle, \& Rubenstein, 2007). Approximately 50\% of the falls occur at home, and can cause fractures, internal bleeding, pneumonia, soft tissue injuries, loss independence, among other consequences (González, Marín, \& Pereira, 2001). One of the most useful strategies for preventing falls is to improve the physical capacities in the elderly (Horne et al., 2014). Moreover, it has been concluded that physical activity leads to improve cognitive functions of the elderly. Also, it can help to reduce the risk of suffering neurodegenerative diseases such as Alzheimer's (Ramos, Romero Ramos, \& González Suarez, 2021). In addition, physical exercise helps to reduce or mitigate the decline of physical capacity in older adults, and therefore, to improve their level of independence (Misic, Valentine, Rosengren, Woods, \& Evans, (2009), to reduce the risk of falling (Sherrington et al., 2017) as well as to prevent the possibility of injury and premature death (Chakravarty, Hubert, Lingala, \& Fries, 2008). Heredia, Rodríguez, \& García (2021) concluded in their research that regular practice of physical activity can lead to improvements in a physical level, health and quality of life of the older people.

Active ageing should be promoted since it can avoid the consequences of functional losses (Ory, Smith, Wade, Mounce, Wilson, \& Parrish, 2010). However, the lack of adherence to physical programs hampers the improvement in the physical condition and consequently abandonment of the training programs (Schwenk, Jordan, Honar vararaghi, Mohler, Armstrong, \& Najafi, 2013; Simek, McPhate, \& Haines, 2012). Physical activity programs can be supported by conventional and technological activities (Paterson \& Warburton, 2010). In fact, previous research has concluded that videogames can help improving the concentration in daily life activities and balance (Santamaría, Salicetti, Moncada, \& Solano, 2018).

Physical exercise based on technological devices seems more common in teenagers (Epstein, Beecher, Graf, \& Roemmich, 2007). It is less common to use in older adults, due to the technological gap that exists between them. It should lead to improving the quality of life since recent research have concluded that digital games help improve physical and cognitive function in older adults (Zhang \& Kaufman, 2016; Salazar, Villar, Párraga, \& Moreno, 2010). Hence, videogames could be a positive support when our objective is to improve physical and cognitive function (Anguera, Gazzaley, Sahakian, \& Kramer, 2015; Ballesteros, Prieto, Mayas, Toril, Pita, Ponce de León, Reales, \& Waterworth, 2014; Horne et al., 2014; IJsselsteijn, Nap, De Kort, \& Poels, 2007; Shah, Weinborn, Verdile, Sohrabi, \& Martins, 2017). Also, it can be used in neurorehabilitation programs (Cameirão, Badia, Oller, \& Verschure, 2010); like in the improvement and recovery of pathologies such as minor depression (Li, Theng, Foo, \& Xu, 2018) and Parkinson's disease (Ferraz, Trippo, Dominguez, Santos, \& Oliveira, 2017). Therefore, it can help in the prevention of falls (Mirelman, Maidan, Herman, Deutsch, Giladi, \& Hausdorff, 2011) since it has shown that digital games increase adherence to a rehabilitation program after falling (Uzor \& Baillie, 2014).

Physical exercise with conventional or technological devices, is one of the best therapies to raise the functionality of anyone who wants to grow, mature, and have healthy ageing. For example, some studies (Chao, Scherer, Wu, Lucke, \& Montgomery, 2013) 
demonstrated that regular exercise using exergames is a potentially effective approach to improve physical function for assisted living facilities residents as well as cognitive function (Zhang \& Kaufman, 2016). Nowadays, there is growing interest in using videogames for improving health and quality of life in older people. Therefore, more research needs to be conducted to increase the knowledge about their benefit in this population. Consequently, the aim of this study was to measure the usefulness of incorporating videogames as a physical activity training program for women above 60 years old.

\section{Methods}

\section{Design}

The used design corresponds to a randomized controlled trial with three groups: two experimental groups and a control group. The control group (CG) made pre-test and post-test, without any intervention of program application. Experimental group 1 (EG1) conducted an aerobic resistance and proprioception training program. Besides, they did a multimedia interaction viso-motor activity (Wii console). Experimental group 2 (EG2) only conducted the training of aerobic resistance and proprioception program.

\section{Participants}

We recruited 52 women. After adaptation program, 43 women remained in our study (age $=67.74 \pm 5.03$ years; weight $=71.80 \pm 11.62 \mathrm{~kg} ; \mathrm{BMI}=31.39 \pm$ $4.58 \mathrm{Kg} / \mathrm{m}^{2}$ ). The $\mathrm{CG}$ consists of 11 participants (age $=$ $67.09 \pm 6.25$ years), the EG1 was composed of 16 subjects (age $=66.94 \pm 4.14$ years). The EG2 consists of 16 participants (age $=69.00 \pm 4.99$ years).

After receiving detailed information on the objectives and procedure, participants provided written informed consent in accordance with the ethical standards established the World Medical Association's Declaration of Helsinki (2013). It was conducted according to the European Community's Guidelines for good clinical practice (Doc. 111/3976/88; July 1990) and the Spanish legal framework for clinical research on humans (Real Decreto 561/1993 on clinical trials).

\section{Procedure}

The participants conducted an adaptation program to familiarize and to learn how to use the technological devices. It took 3 sessions in a week (non-consecutive days). Three groups randomly composed of seventeen, seventeen, and eighteen subjects (52 subjects) were established. The first group practiced with static bikes for twenty minutes. The second group did balance exercises for twenty minutes. The third group practiced with the video game console for another twenty minutes. They changed the activity after the established practice time, passing through the three stations.

\section{Data Analysis}

Experimental groups were defined following a personal preference for practice or not with theWii console. Both groups were formed following a balance in relation to the number of subjects and their baseline characteristics. We performed chi-square test to establish the homogeneity of groups (age: $p=.490$; weight: $p=.198$; BMI: $p=.132$; fat mass: $p=.250$; lean mass: $p=.193)$. In addition, we conducted ANOVA to confirm the homogeneity of groups. We obtained that there are no significant differences among groups, thus the final allocation of the participants does not have an influence on the final results.

\section{Initial and Final Evaluation}

Initial and final evaluations were carried out sequentially during the same session to all participants. We used a size meter model Sayol (SL, Barcelona) to measure their height. Body composition was measured by bioelectrical impedance technique (Kyle et al., 2004; Perissinotto, Pisent, Sergi, Grigoletto, \& Enzi, 2002) andTanita device (SC330). We conducted the monopodal balance test to measure the balance (with and without vision). Eye-hand coordination (manual agility) was measured using the plates of the dominant hand punching test (Camiña, Cancela, \& Romo, 2001). The strength of the lower limbs was evaluated with counter movement jump (CMJ) test. We used OptoGait system (Microgate, Bolzano, Italy) to record the data. It has been used in similar studies (Dionyssiotis, Galanos, Michas, \& Lyritis, 2009). Finally, we measure the cardiorespiratory resistance using the walking test (Camiña et al., 2001) and we recorded the heart rate of the participants throughout the test to check the physical condition. For that, we used the sensors of the static bike Mundial Silver Línea Tentabla to determinate the $\mathrm{VO}_{2}$ máx.

\section{Practical Session}

The experimental treatment was carried out for 12 weeks ( 3 sessions a week each group). The sessions for EG2 lasted 40 minutes, whereas for EG1 the sessions lasted 60 minutes, since this group performed an 
additional activity with the Wii console. Both groups performed a standard warm-up (10 minutes). In both cases it was established a work routine that responds to a progression in intensity.

Every group performed 20 minutes at each station (static bike or balance). Once, the time was completed, EG2 ended their session. Whilst, EG1 moved to the third station. On it, they had to play with a video game console (Wii). They played a tennis video game (video game
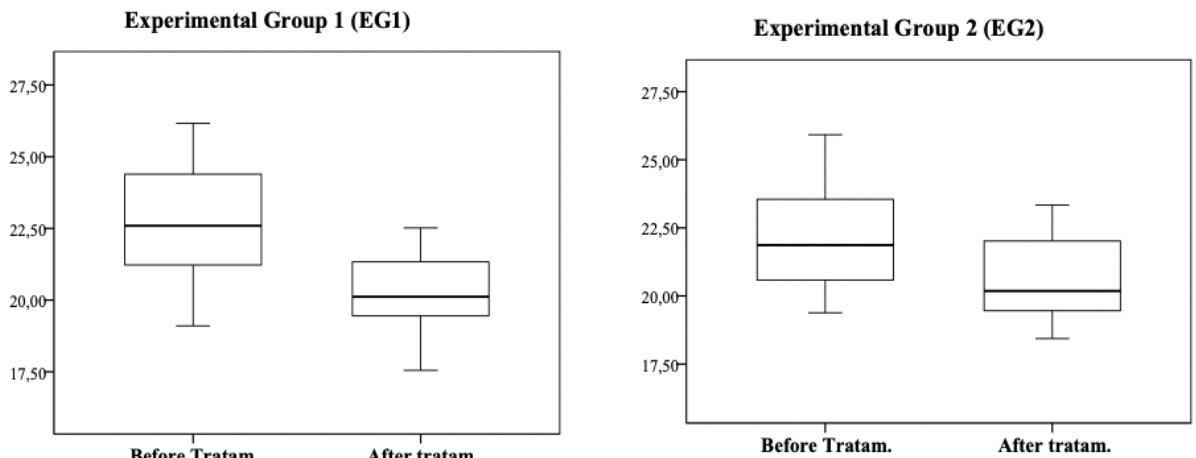

Figure 1. Time spent in cardio-respiratory resistance before and after the treatment in EG1 and EG2.
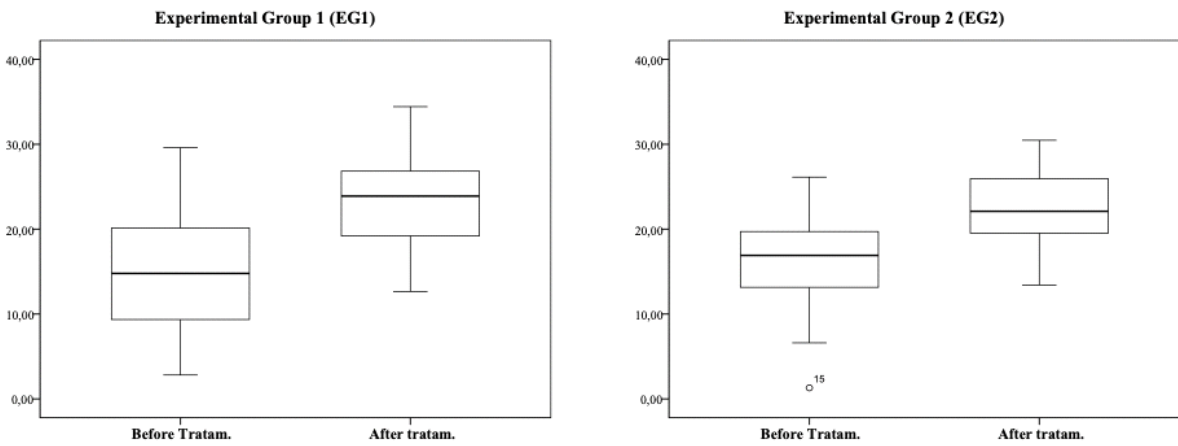

Figure 2. $\mathrm{VO}_{2}$ máx. in cardio-respiratory resistance before and after the treatment in EG1 and EG2.

Wii Sport, tennis) in couples (1 versus 1 modality) for difference in BMI $(p=.006)$ was found. 20 minutes.

\section{Results}

Table 1 presents the results obtained after the exercise program. We found significant differences in the monopodal static balance variable with vision in the EG1 ( $p=.008)$, and EG2 ( $p=.062)$. Also, significant differences were found for balance without vision in EG1 $(p=.001)$. However, we did not find significant differences in EG2 $(p=.508)$ for this variable. Regarding the manual grip, we found significant differences in no dominant hand isometric maximum strength variable in EG1 ( $p=.02)$, and EG2 ( $p=.018)$.

Concerning the time required to complete the gait test, we found significant differences in both groups $(p<.001)$. Notice that EG1 got a greater time reduction than EG2. About $\mathrm{VO}_{2} \max$, we found significant differences in EG1 and EG2 ( $p<.001)$ (Figure 1 and 2).

We did not find significant differences in body weight in EG1 $(p=.178)$. Regarding to fat mass, significant differences were found $(p=.048)$. Lean mass did not show significant differences $(p=.183)$. Concerning to BMI, we did not find significant differences $(p=.116)$ in EG1. We found significant differences in EG2 for body weight variable $(p=.017)$. Also, significant difference in fat mass was found $(p=.008)$. In addition, a significant
We apply ANOVA test to analyse differences between groups (table 2). We have found significant

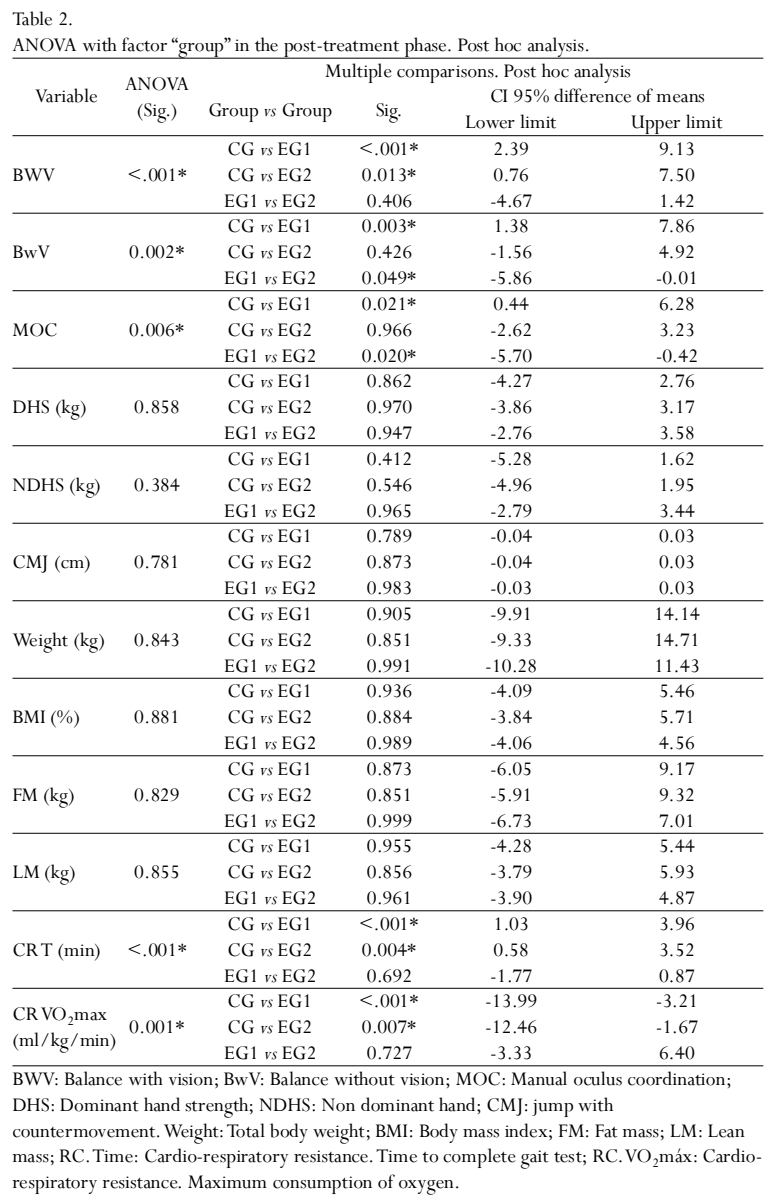


Table 1

\begin{tabular}{|c|c|c|c|c|c|c|c|c|c|c|c|c|}
\hline \multirow[b]{2}{*}{ Variable } & \multicolumn{4}{|c|}{ Control Group (CG) } & \multicolumn{4}{|c|}{ Experimental Group 1 (EG1) } & \multicolumn{4}{|c|}{ Experimental Group 2 (EG2) } \\
\hline & $\begin{array}{c}\text { Pre-test } \\
\text { Mean } \pm \text { SD }\end{array}$ & $\begin{array}{c}\text { Post-test } \\
\text { Mean } \pm \text { SD }\end{array}$ & $\begin{array}{c}\mathrm{p} \\
\text { (sig) }\end{array}$ & $\begin{array}{c}95 \% \text { confid. } \\
\text { intervals }\end{array}$ & $\begin{array}{c}\text { Pre-test } \\
\text { Mean } \pm \text { SD }\end{array}$ & $\begin{array}{c}\text { Post-test } \\
\text { Mean } \pm \text { SD }\end{array}$ & $\begin{array}{c}\mathrm{p} \\
\text { (sig) }\end{array}$ & $\begin{array}{c}95 \% \\
\text { confid. intervals }\end{array}$ & $\begin{array}{c}\text { Pre test } \\
\text { Mean } \pm \text { SD }\end{array}$ & $\begin{array}{c}\text { Post test } \\
\text { Mean } \pm \text { SD }\end{array}$ & $\underset{(\mathrm{sig})}{\mathrm{p}}$ & $95 \%$ confid. intervals \\
\hline$\overline{\mathrm{BWV}}$ & $8.00 \pm 4.83$ & $8.82 \pm 4.09$ & 0.314 & $-2.54 ; 0.90$ & $5.50 \pm 4.15$ & $3.06 \pm 3.38$ & 0.008 & $0.73 ; 4.14$ & $6.06 \pm 4.07$ & $4.69 \pm 2.82$ & 0.062 & $-0.08 ; 2.83$ \\
\hline $\mathrm{BwV}$ & $12.45 \pm 3.93$ & $12.18 \pm 3.60$ & 0.661 & $-1.07 ; 1.62$ & $10.63 \pm 4.59$ & $7.56 \pm 3.43$ & 0.001 & $1.41 ; 4.72$ & $11.38 \pm 5.06$ & $10.50 \pm 2.80$ & 0.508 & $-1.87 ; 3.63$ \\
\hline MOC & $19.21 \pm 5.11$ & $17.46 \pm 3.44$ & 0.119 & $-0.53 ; 4.01$ & $13.80 \pm 3.01$ & $14.11 \pm 2.53$ & 0.340 & $-0.95 ; 0.35$ & $17.05 \pm 3.55$ & $17.16 \pm 2.95$ & 0.883 & $-1.72 ; 1.49$ \\
\hline DHS (kg) & $19.73 \pm 3.76$ & $20.90 \pm 3.18$ & 0.157 & $-2.88 ; 0.53$ & $22.61 \pm 4.69$ & $21.66 \pm 3.65$ & 0.207 & $-0.58 ; 2.48$ & $22.24 \pm 3.36$ & $21.24 \pm 3.63$ & 0.092 & $-0.18 ; 2.17$ \\
\hline NDHS (kg) & $17.27 \pm 3.42$ & $17.93 \pm 3.36$ & 0.310 & $-2.02 ; 0.71$ & $21.53 \pm 3.94$ & $19.76 \pm 3.46$ & 0.020 & $0.32 ; 3.23$ & $21.03 \pm 3.03$ & $19.43 \pm 3.54$ & 0.018 & $0.32 ; 2.88$ \\
\hline $\mathrm{CMJ}(\mathrm{cm})$ & $0.07 \pm 0.04$ & $0.07 \pm 0.04$ & 0.146 & $-0.01 ; 0.00$ & $0.08 \pm 0.04$ & $0.08 \pm 0.04$ & 0.187 & $-0.02 ; 0.00$ & $0.08 \pm 0.03$ & $0.08 \pm 0.03$ & 0.212 & $-0.01 ; 0.00$ \\
\hline Weight (kg) & $73.18 \pm 13.26$ & $73.11 \pm 13.26$ & 0.678 & $-0.31 ; 0.45$ & $71.50 \pm 11.87$ & $70.99 \pm 12.4$ & 0.178 & $-0.24 ; 1.19$ & $71.19 \pm 10.86$ & $70.42 \pm 10.85$ & 0.017 & $0.16 ; 1.38$ \\
\hline BMI (\%) & $32.4 \pm 5.23$ & $32.28 \pm 5.25$ & 0.090 & $-0.02 ; 0.26$ & $31.86 \pm 4.31$ & $31.60 \pm 4.51$ & 0.116 & $-0.07 ; 0.58$ & $31.69 \pm 4.66$ & $31.35 \pm 4.75$ & 0.006 & $0.11 ; 0.57$ \\
\hline FM (kg) & $29.56 \pm 8.43$ & $28.97 \pm 8.25$ & 0.066 & $-0.05 ; 1.21$ & $28.24 \pm 7.61$ & $27.41 \pm 7.61$ & 0.048 & $0.01 ; 1.64$ & $28.33 \pm 7.68$ & $27.27 \pm 7.25$ & 0.008 & $0.32 ; 1.80$ \\
\hline LM (kg) & $43.63 \pm 5.31$ & $44.16 \pm 5.35$ & 0.014 & $-0.94 ;-0.14$ & $43.23 \pm 4.92$ & $43.58 \pm 5.36$ & 0.183 & $-0.88 ; 0.18$ & $42.86 \pm 3.63$ & $43.09 \pm 3.96$ & 0.497 & $-0.96 ; 0.49$ \\
\hline CR T (min) & $22.49 \pm 1.23$ & $22.64 \pm 1.47$ & 0.244 & $-0.16 ; 0.55$ & $22.70 \pm 2.09$ & $20.15 \pm 1.47$ & $<.001$ & $1.52 ; 3.58$ & $22.20 \pm 2.00$ & $20.59 \pm 1.47$ & $<.001$ & $0.96 ; 2.24$ \\
\hline $\mathrm{CRVO}_{2} \max (\mathrm{ml} / \mathrm{kg} / \mathrm{min})$ & $15.87 \pm 4.98$ & $14.93 \pm 5.36$ & 0.097 & $-0.20 ; 2.08$ & $15.04 \pm 7.91$ & $23.56 \pm 6.05$ & $<.001$ & $-11.85 ;-5.14$ & $16.18 \pm 6.42$ & $22.00 \pm 4.74$ & $<.001$ & $-7.52 ;-4.12$ \\
\hline
\end{tabular}

differences in monopodal balance with vision $(p<.001)$; monopodal balance without vision $(p=.002)$; oculus manual coordination $(p=.006)$ time required to complete gait test $(p<.001)$ and $\mathrm{VO}_{2}$ máx $(p=.001)$.

\section{Discussion}

The study aimed to measure the usefulness of incorporating videogames as a physical activity training program for women above 60 years old. Our results show that a training program that adds the use of videogames to proprioceptive and aerobic resistance exercises can improve monopodal static balance, with and without vision. It is important for daily activities and is considered beneficial to prevent falls in women over 60 years.

It is important to note that there are a lot of variables which should be considered in a training program. Duration time program is an important variable to consider when we design a training program. There is previous research with shorter, equal, or greater experimental time (Flack et al., 2011). In our study, intervention time was enough to obtain significant differences in some variables. It would be desirable to increase it in order to know if a greater time training produces greater improvements in the variables analysed. It seems to happen in the longer-term interventions (Santanasto, Glynn, Newman, Taylor, Brooks, Goodpaster and Newman, 2011).

Intensity and volume are variables that can modify the final result during the intervention programs. A well-evaluated training program allows increasing workload and adapts to the participants the intensity and volume during the intervention. It can improve the quality of life, cognitive function, as well as the level of balance and flexibility (Chao, Scherer, Wu, Lucke, \& Montgomery, 2013; Williams, Soiza, Jenkinson, \& Stewart, 2010). In our study, EG1 and EG2 had the same intensity level during the training sessions. Thus, the significant differences that we found in the variables analysed are not due to changes in intensity during the training sessions. It should be noted that the workload volume was different since EG1 performed 20 minutes longer (playing videogames) than EG2 during the training sessions. Volume difference can be a limitation of our study since more time spent playing videogames can modify the final results. Future research needs to be conducted with the same volume workload so we can determine which experimental group obtains better results.

Concerning body composition, it seems that it takes at least 3 sessions per week to produce improvements. In addition, we can make caloric restriction during the intervention with physical exercise. It allows us to obtain significant differences in body composition with less than three weekly sessions (Santanasto et al., 2011). In regard to weight, BMI, and fat mass, EG2 showed significant differences. It is in concordance with previous research (van den Berg, Elders, De Zwart, \& Burdorf, 2008). Noticed that lean mass did not increase in EG1 nor EG2. Nonetheless, it can be considered a positive result due to the increase of sarcopenia that occurs at these ages (Janssen, 2010; Lang, Streeper, Cawthon, Baldwin, Taaffe, \& Harris, 2010).

Balance is essential to maintain a good level of capacity in ageing, due to the relationship between mobility, falls, and balance (Agmon, Perry, Phelan, Demiris \& Nguyen, 2011; Blank et al., 2011; Meisler et al., 2011; Ruthig et al., 2007; Scheffer et al., 2007). Our results show that a proprioceptive training complemented with videogames, produces significant differences in monopodal balance with and without vision. Both groups got a decrease on the surface used by the free foot on the ground to maintain balance. In EG1, significant differences were obtained in balance (with and without vision). Whereas, EG2 had slight 
differences in balance without vision. The difference between groups may be due to the longer training time for visual perception that EG1 received.

It seems that the use of new technologies that involve training of visual perception improves the balance in older adults. It allows to avoid falls in this population (Cameirão et al., 2010; IJsselsteijn, Nap, De Kort, \& Poels, 2007; Mirelman, Maidan, Herman, Deutsch, Giladi, \& Hausdorff, 2011). It is confirmed in our research with the implementation of the program of intervention with the Wii console and the Wii Sports game.

According to eye-hand coordination, our results are in concordance with previous studies (Kosse \& Maartenskliniek, 2011). The uses of exergames improve this capacity in EG1.

In relation to the handgrip isometric strength, we did not find significant differences. A reason for that could be the use of the dominant hand in everyday tasks. Therefore, is not necessary to implement a specific training program to keep the level of the force. Nonetheless, the results showed significant differences in the non-dominant hand. The participants did not a specific training program so the value of hand strength decreases due to the degenerative process that occurs at this age. This decline in strength is related to lower abilities, an increase of falls, as well as being a factor predictor of the difficulties of the elderly in their daily activities (Hernandez et al., 2010; Van den Berg, Elders, de Zwart, \& Burdorf, 2008).

In cardio-respiratory resistance, we found significant differences in both groups compared with the control group. Both experimental groups decreasing the time spent to complete the task and increasing the $\mathrm{VO} 2 \mathrm{max}$ value. $\mathrm{VO} 2 \mathrm{max}$ is considered a sign of vitality in older adults. Also, it is related to their cognitive ability which can be reduced at these ages (Chakravarty et al., 2008; Fleg, J. L., Morrell, Bos, Brant, Talbot, Wright, \& Lakatta, 2005; Van den Berg et al., 2008).

We did not find significant differences in some variables analysed in our study. A reason for that can be placed in the temporal difference of the treatment, the intensity and volume difference of the workload or the specific nature of the tasks performed.

In conclusion, joining a physical training program, including proprioceptive and aerobic resistance exercises result in a weight and BMI drop, and a VO2max improvement for older people. Additionally, should be noted that if the training program is completed with the use of exergames in videogame console, monopodal static balance improves, with and without vision. It is considered beneficial to prevent falls of elderly people.

\section{Practical Application}

Nowadays, it is necessary to emphasize that promote active ageing is an essential task to improve the quality of life of older adults. It generates many benefits such as the prevention of falls, early mortality decline, and higher rates of overall vitality in the population.

Exergames should be taken into account when designing a training program for people over 60 years of age. It can help improve physical capacities and neuromuscular aspects. In addition, exergames allow to break the technological gap between generations since older adults and their grandson/child could use videogames in their free time.

\section{References}

Agmon,M.,Perry, C.K.,Phelan,E., Demiris, G., \& Nguyen,H.Q. (2011).A pilotstudy ofWii Fit exergames toimprovebalance in older adults. Journal of Geriatric Physical Therapy, 34(4), 161167.https://doi.org/10.1519/JPT.0b013e3182191d98

Anguera,J.A., Gazzaley,A.,Sahakian, B. J., \& Kramer,A.F.(2015). Video games, cognitive exercises, and the enhancement of cognitive abilitiesThis review comes from a themed issue on Cognitive enhancement. Current Opinion in Behavioral Sciences, 4, 160-165. https://doi.org/10.1016/ j.cobeha.2015.06.002

Ballesteros, S.,Prieto,A., Mayas,J.,Toril,P.,Pita,C.,PoncedeLeón, L., Reales, J.M., \&Waterworth,J. (2014). Brain training with non-action videogames enhances aspects of cognition in older adults: a randomized controlled trial. Frontiers in Aging Neuroscience, 6, 277. https://doi.org/10.3389/ fnagi.2014.00277

Blank,W.A., Freiberger,E., Siegrist,M.,Landendoerfer,P.,Linde, K., Schuster,T., ...,\& Halle, M. (2011).An interdisciplinary intervention to prevent falls in community-dwelling elderly persons: Protocol of a cluster-randomized trial [PreFalls]. BMC Geriatrics, 11(1), 7. https://doi.org/10.1186/1471-231811-7

Caicedo,P.E., Rengifo, C.F., \& Rodríguez,L.E.(2016). Contribuciones de las ciencias electrónicas al problema de las caídas en poblaciónadulta mayor. Revista Mexicana de Ingenieria Biomedica, 37(3), 251-269. https://doi.org/10.17488/RMIB.37.3.6

Cameirão, M. S., Badia, S. B. I., Oller, E. D., \& Verschure, P. F. (2010). Neurorehabilitation using the virtual reality based Rehabilitation Gaming System: methodology, design, psychometrics, usability and validation. Journal of 
Neuroengineering and Rehabilitation, 7(1), 48.

https: / / doi.org/10.1186/1743-0003-7-48

Camiña,F., Cancela,J.M., \& Romo,V.(2001).The prescription of the physical exercise for elders. Normative values of thefitness. $1,136-154$.

Chakravarty, E.F., Hubert, H. B., Lingala,V.B., \& Fries, J.F.(2008). Reduced disability and mortality among aging runners: $\mathrm{a} 21$ year longitudinal study. Archives of Internal Medicine, 168(15), 1638-1646. https: / / doi.org/10.1001/ archinte. 168.15 .1638

Chao,Y.-Y., Scherer,Y.K., Montgomery, C.A.,Wu,Y.-W., \& Lucke, K. T. (2014). Physical and Psychosocial Effects of Wii Fit Exergames Use in Assisted Living Residents: A Pilot Study. Clinical Nursing Research. https: / / doi.org/10.1177/ 1054773814562880

Chao,Y., Scherer,Y.K.,Wu,Y., Lucke, K.T., \& Montgomery, C.A. (2013). The feasibility of an intervention combining self-efficacy theory andWii Fit exergames in assisted living residents / :A pilot study. JUNE. https: / / doi.org/10.1016/j.gerinurse.2013.05.006

Dionyssiotis,Y., Galanos, A., Michas, G., \& Lyritis, G. P. (2009). Assessment of musculoskeletal system in women with jumping mechanography. 113-118.

Epstein, L. H., Beecher, M. D., Graf, J. L., \& Roemmich, J. N. (2007). Choice of interactive dance and bicycle games in overweight and nonoverweight youth. Annals of Behavioral Medicine, 33(2), 124-131. https://doi.org/10.1007/ $\mathrm{BF} 02879893$

Ferraz, D. D.,Trippo, K., Dominguez,A., Santos,A., \& Oliveira Filho,J.(2017). NintendoWii training on postural balance and mobility rehabilitation of adults with Parkinson's disease: a systematicreview. Fisioterapia Em Movimento, 30(suppl 1), 383 393. https://doi.org/10.1590/1980-5918.030.s01.ar07

KyleD. Flack, Kevin P.Davy,MatthewW.Hulver, RichardA.Winett, MadlynI. Frisard, BrendaM. Davy. «Aging, ResistanceTraining, and Diabetes Prevention», Journal of Aging Research, vol. 2011,ArticleID 127315, 12 pages, 2011.https: / /doi.org/ $10.4061 / 2011 / 127315$

Fleg, J. L., Morrell, C. H., Bos, A. G., Brant, L. J., Talbot, L.A., Wright, J. G., \& Lakatta, E. G. (2005).Accelerated longitudinal decline of aerobic capacity in healthy older adults. Circulation, 112(5), 674-682. https://doi.org/10.1161/ CIRCULATIONAHA.105.545459

Ganz,D.A., Bao,Y., Shekelle,P.G., \& Rubenstein,L.Z.(2007).Will my patient fall? JAMA, 297(1), 77-86. https://doi.org/ 10.1001/jama.297.1.77

González, G., Marín, P.P., \& Pereira, G. (2001).[Characteristics of falls among free living elders]. Revista Médica de Chile, 129(9), 1021-1030.

Guzmán, K. S., Fonseca,A. S., Jiménez, J. M., \& Mora, L. C. S. (2018). Mejora del equilibrio, atención y concentración después de un programa de entrenamiento exergame en lapersonaadulta mayor. Retos:nuevastendencias en educación fisica, depor- te y recreación, (33), 102-105.

Heredia, N. M., Rodríguez, E.S., \& García,A.M.R.(2021). Beneficios de la actividad física para la promoción de un envejecimiento activo en personas mayores: revisión bibliográfica. Retos: nuevastendencias en educación fisica, deporte y recreación, (39), 12.

Hernandez, M. E., Goldberg, A., \& Alexander, N. B. (2010). Decreased muscle strength relates to self-reported stooping, crouching, or kneeling difficultyin olderadults. PhysicalTherapy, 90(1), 67-74. https: / /doi.org/10.2522/ptj.20090035

Hill,E.E., Nguyen,T.H., Shaha,M.,Wenzel, J.A., DeForge, B. R., \& Spellbring,A.M.(2009). Person-environmentinteractions contributing to nursing home resident falls. Research in Gerontological Nursing, 2(4), 287-296. https://doi.org/ 10.3928/19404921-20090527-02

Horne, M., Skelton, D. A., Speed, S., \& Todd, C. (2014). Falls Prevention and theValue of Exercise: Salient Beliefs Among South Asian andWhite British Older Adults. Clinical Nursing Research, 23(1), 94-110. https://doi.org/10.1177/ 1054773813488938

IJsselsteijn,W., Nap,H.H., De Kort,Y., \& Poels, K. (2007). Digital game design for elderly users. Proceedings of the 2007 Conference on Future Play, Future Play '07, 17-22. https: / / doi.org/ $10.1145 / 1328202.1328206$

Janssen, I. (2010). Evolution of sarcopenia research. Applied Physiology, Nutrition, and Metabolism = Physiologie Appliquée, Nutrition et Métabolisme, 35(5), 707-712. https: / /doi.org/ 10.1139/H10-067

Jin, K., Simpkins, J.W., Ji, X., Leis, M., \& Stambler, I. (2015). The critical need to promote research of aging and aging-related diseases to improve health and longevity of the elderly population. Aging and Disease, 6(1), 1-5. https://doi.org/ 10.14336/AD.2014.1210

Kosse, N., \& Maartenskliniek, S. (2011). Exergaming/:Interactive balance training in healthy community-dwelling older adults ExErgamIng/:IntEractIvE BalancE traInIng In hEalthy communlty. October 2015.

Kyle, U. G., Bosaeus, I., Lorenzo,A. D. De, Manuel, G., Lilienthal, B., Kent-smith, L., Melchior, J., Pichard, C., \& Group, W. (2004). Bioelectrical impedance analysis $F$ part $I /$ : review of principles and methods. 1226-1243. https://doi.org/10.1016/ j.clnu.2004.06.004

Lang,T., Streeper, T., Cawthon, P., Baldwin, K., Taaffe, D. R., \& Harris,T.B. (2010). Sarcopenia:Etiology, clinical consequences, intervention, and assessment. Osteoporosis International, 21 (4), 543-559. https: / /doi.org/10.1007/s00198-009-1059-y

Li,J.,Theng,Y.L., Foo,S., \& Xu, X. (2018).Exergamesvs.traditional exercise: investigating the influencing mechanism of platform effect on subthreshold depression among older adults. Aging and Mental Health, 22(12), 1634-1641. https://doi.org/ 10.1080/13607863.2017.1385722

Martínez, C. S., Ortega, M.V., Montilla, J.A. P., \& Moreno, R. 
(2010). Efectos de la utilización de los videojuegos en un programa de mejora del equilibrio en mujeres de 60 años o más. Retos. Nuevastendencias en Educación Física, Deportey Recreación, (17), 93-95.

McNaull, B. B.A., Todd, S., McGuinness, B., \& Passmore, A. P. (2010). Inflammation and anti-inflammatory strategies for Alzheimer's disease - amini-review. Gerontology, 56(1), 3-14. https: / /doi.org/10.1159/000237873

Meisler,R.,Thomsen,A. B.,Theilade,P.,Abildstrøm,H., Borge, P., Treschow, M., .. .,\& Rasmussen, L. S. (2011). Age-related differencesinmechanism, cause, and location of trauma deaths. Minerva Anestesiologica, 77(6), 592-597.

Mirelman,A., Maidan,I., Herman,T., Deutsch, J.E., Giladi, N., \& Hausdorff,J. M.(2011).Virtual reality for gait training: can it induce motor learning to enhance complex walking and reduce fall risk in patients with Parkinson's disease? The Journals of Gerontology.SeriesA,Biological Sciences and Medical Sciences, 66(2), 234-240.https: / /doi.org/10.1093/gerona/glq201

Misic, M. M., Valentine, R. J., Rosengren, K. S., Woods, J.A., \& Evans, E. M. (2009). Impact of training modality on strength and physical function in older adults. Gerontology, 55(4), 411416. https: / / doi.org/10.1159/000227804

Ory, M. G., Smith, M. L., Wade,A., Mounce, C., Wilson,A., \& Parrish, R. (2010). Implementing and Disseminating an Evidence-Based Program to Prevent Falls in Older Adults, Texas, 2007-2009. Preventing Chronic Disease, 7(6), A130.

Paterson,D. H., \&Warburton, D.E. (2010). Physical activity and functional limitationsinolderadults:A systematicreview related to Canada's Physical Activity Guidelines. International Journal of Behavioral Nutrition and Physical Activity, 7(1), 38. https: / / doi.org/10.1186/1479-5868-7-38

Perissinotto,E.,Pisent, C., Sergi, G., Grigoletto,F., \&Enzi, G.(2002). Anthropometricmeasurementsin the elderly: age and gender differences. British Journal of Nutrition, 87(2), 177-186. https:/ /doi.org/10.1079/bjn2001487

Rahman, K. (2007). Studies onfreeradicals, antioxidants, and cofactors. Clinical Interventions in Aging, 2(2), 219-236.

Ramos, N. R., Ramos, Ó. R., \& Suárez,A. J. G. (2021).Actividad física y funciones cognitivas en personas mayores: revisión sistemática de losúltimos 5 años. Retos: nuevastendencias en educación fisica, deporte y recreación, (39), 81.

Ruthig, J. C., Chipperfield, J. G., Newall,N. E., Perry, R. P., \& Hall, N. C. (2007). Detrimental effects of falling on health and wellbeing in later life: the mediating roles of perceived control and optimism. Journal of Health Psychology, 12(2), 231-248.https: / /doi.org/10.1177/1359105307074250

Santanasto,A.J., Glynn,N.W.,Newman,M.A.,Taylor,C.A., Brooks, M.M., Goodpaster, B.H., \& Newman,A.B.(2011). Impactof weight loss on physical function with changes in strength, muscle mass, and muscle fat infiltration in overweight to moderately obese older adults: A randomized clinical trial. Journal of Obesity, 2011. https://doi.org/10.1155/2011/
516576

Scheffer,A.C., Schuurmans,M.J., vanDijk, N., vanderHooft,T., \& de Rooij, S. E. (2007). Fear of falling: measurement strategy, prevalence, risk factors and consequences among older persons. Age and Ageing, 37(1), 19-24. https://doi.org/ 10.1093/ageing/afm169

Schwenk, M., Jordan, E. D. H., Honarvararaghi, B., Mohler, J., Armstrong, D. G., \& Najafi, B. (2013). Effectiveness of foot and ankle exercise programs on reducing the risk of falling in older adults: A systematic review and meta-analysis of randomized controlled trials. Journal of the American Podiatric Medical Association, 103(6), 534 547. https://doi.org/ 10.7547/1030534

Shah,T.M.,Weinborn,M.,Verdile, G., Sohrabi,H. R., \& Martins, R. N. (2017). Enhancing Cognitive Functioning in Healthly Older Adults: a Systematic Review of the Clinical Significance of Commercially Available Computerized CognitiveTraining in Preventing Cognitive Decline. Neuropsychology Review, 1-19. https: / / doi.org/10.1007/s11065-016-9338-9

Sherrington, C., Michaleff,Z.A., Fairhall, N., Paul, S.S.,Tiedemann, A.,Whitney, J. . . Lord, S. R. (2017). Exercise to preventfalls in olderadults:Anupdated systematicreview andmeta-analysis. British Journal of Sports Medicine, 51(24), 1749-1757. https:/ / doi.org/10.1136/bjsports-2016-096547

Shields, M.,Tremblay, M. S., Laviolette, M., Craig, C.L., Janssen, I., \& Gorber, S. C. (2010). Fitness of Canadian adults: results from the 2007-2009 Canadian Health Measures Survey. Health Reports / Statistics Canada, Canadian Centrefor Health Information $=$ Rapports Sur La Santé / Statistique Canada, Centre Canadien d'information Sur La Santé, 21(1), 21-35.

Simek, E. M., McPhate, L., \& Haines, T. P. (2012).Adherence to and efficacy of home exercise programs to prevent falls: A systematic review and meta-analysis of the impact of exercise program characteristics. Preventive Medicine, 55(4), 262-275. https: / /doi.org/10.1016/j.ypmed.2012.07.007

Uzor, S., \& Baillie, L. (2014). Investigating the long-term use of exergamesin the home withelderly fallers. Conference on Human Factors in Computing Systems - Proceedings, 2813-2822.https: / /doi.org/10.1145/2556288.2557160

vanden Berg,T., Elders, L., deZwart,B., \& Burdorf,A.(2008).The effects of work-related and individual factors on the Work Ability Index: a systematic review. Occupational and environmental medicine, 66(4), 211-220.

Williams, M.A., Soiza, R. L., Jenkinson, A. M., \& Stewart,A. (2010). EXercising with Computers in Later Life (EXCELL)-pilot and feasibility study of the acceptability of the Nintendo ${ }^{\mathrm{R}}$ WiiFit in community-dwelling fallers.

Zhang, F., \& Kaufman, D. (2016). Physical and Cognitive Impacts of Digital Games on OlderAdults: A Meta-Analytic Review. Journal of Applied Gerontology, 35(11), 1189-1210. https: / / doi.org/10.1177/0733464814566678 